\title{
KAJIAN BIOEKOLOGI IKAN KARANG CHAETODONTIDAE SEBAGAI SALAH SATU INDIKATOR UNTUK MENDETEKSI KONDISI EKOSISTEM TERUMBU KARANG DI PERAIRAN TAMAN NASIONAL KEPULAUAN TOGEAN, SULAWESI TENGAH
}

\author{
STUDY OF CHAETODONTIDAE FISH BIOECOLOGY AS ONE OF THE INDICATORS TO \\ DETECT THE CONDITIONS OF CORAL REEF ECOSYSTEMS IN THE TOGEAN ISLANDS \\ NATIONAL PARK, CENTRAL SULAWESI
}

\author{
Ratna Suharti", Kresna Yugha Saktiawan, Basuki Rachmad, Heri Tryono dan Dadan Zulkifli \\ Teknologi Pengelolaan Sumberdaya Perairan, Sekolah Tinggi Perikanan Jakarta 12520, Indonesia \\ * Korespondesi Penulis: ratnastp.rs75@gmail.com
}

Diterima: 24 Oktober 2018; diterima setelah perbaikan: 30 Oktober 2018; Disetujui: 10 November 2018

\begin{abstract}
ABSTRAK
Taman Nasional Kepulauan Togean memiliki kekayaan hayati bawah laut sangat besar, salah satunya adalah ikan family Chaetodontidae yang memiliki keterkaitan erat dengan kondisi fisik terumbu karang sehingga ikan ini dapat dijadikan sebagai indikator kondisi ekosistem terumbu karang. Penelitian ini dilakukan dengan tujuan mengamati komposisi jenis dan sebaran serta mengkaji bioekologi ikan famili Chaetodontidae di perairan Taman Nasional Kepulauan Togean, Provinsi Sulawesi Tengah yang dilaksanakan di 15 stasiun pada bulan Februari - Mei 2017. Pengambilan data ikan menggunakan metode UVC. Analisis isi lambung dilakukan menggunakan metode index of preponderance (IP). Komposisi ikan Family Chaetodontidae di Taman Nasional Kepulauan Togean terdiri dari 12 spesies dari 3 genera. Indeks keanekaragaman $\left(H^{\prime}\right)$ berkisar antara 0,92 - 2,05, indeks keseragaman (E) berkisar antara 0,83 - 1,00 serta indeks dominansi (C) berkisar antara 0,14 - 0,44. Hasil analisis makanan pada Family Chaetodontidae ditemukan 8 jenis makanan, dan bersifat hard coral feeder. Berdasarkan penilaian ekologi mengindikasikan bahwa keadaan terumbu karang di perairan Taman Nasional Kepulauan Togean masih dalam keadaan baik, kecuali pada Pulau Waleakodi cenderung telah mengalami kerusakan. Pengelompokan kesamaan spesies membentuk kelompok yang mengerucut ke perairan Pulau Togean, menunjukkan bahwa hampir seluruh spesies ikan family Chaetodontidae ditemukan terdapat di Pulau Togean.Parameter perairan meliputi kecepatan arus, salinitas dan suhu tergolong layak.
\end{abstract}

Kata kunci : Bioekologi, Chaetodontidae, UVC, TN Kepulauan Togean

\begin{abstract}
Togean National Park has a rich marine biodiversity, one of them is fish of the Chaetodontidae family that has a close relationship with the physical condition of coral reefs, so this fish can be used as an indicator of the condition of the coral reef ecosystems. This research was conducted with the aim of observing the composition of species and their distribution and studying the bioecology of fish of Chaetodontidae family in the waters of the Togean Islands National Park, Central Sulawesi Province, which was conducted in 15 stations in February - May 2017. The fish data was taken by using the UVC method and the analysis of gastric contents was carried out by using the index of preponderance (IP) method. The composition of fish of the Family of Chaetodontidae in Togian Islands National Park comprises 12 species in 3 genera. The index of diversity $\left(H^{\prime}\right)$ ranged from $0.92-2.05$, uniformity index $(E)$ ranges between $0.831 .00-$ as well as dominance index $(C)$ ranged from $0.14-0.44$. The analysis results of food of the Family Chaetodontidae was found 8 kinds of food, and hard coral feeder. Based on ecological assessment, it indicates that the condition of the coral reefs in the waters of Togean National Park is still in good, but the condition of coral reefs on the island of Waleakodi tends to have suffered damages.
\end{abstract}

Keyword : Bioecology, Chaetodontidae, UVC, Togean National Park

Copyright (C) Jkpt Juni 2018

Kajian Bioekologi Ikan Karang Chaetodontidae ........Suharti, et.al 


\section{PENDAHULUAN}

Salah satu kelompok biota yang hidup berasosiasi dengan terumbu karang dan memegang peranan penting di dalam ekosistem terumbu karang adalah ikan Chaetodontidae. Ikan Chaetodontidae dikenal juga dengan butterflyfishes merupakan salah satu ikan terumbu karang yang mudah dikenali diperairan terumbu karang (Maharbhakti, 2009). Pada umumnya ikan Chaetodontidae memiliki mulut lancip dan rahangnya dilengkapi dengan gigi-gigi kecil dan tajam untuk mencari makanannya di karang berbatu, adapun yang mempunyai gigi mirip dengan sisir (Madduppa, 2006). Ikan Chaetodontidae merupakan ikan yang penyebarannya hanya disekitar terumbu karang dan akan dijumpai pada setiap terumbu karang, dimana ikan ini akan dijumpai pada komunitas terumbu karang dalam keadaan baik (Suryanti, Supriharyono dan Wily, 2011). Menurut Hukom dan Bawole (1997) dan Titaheluw (2011), famili Chaetodontidae lebih kaya jenisnya pada daerah terumbu karang yang didominasi oleh karang Acropora yang merupakan tipe long branching colonies. Beberapa jenis ikan ini yang menempati karang Acropora diantaranya Chaetodon auriga, C. citrinelus dan C. oktofaskiatus. Khusus untuk jenis $C$. oktofasciatus jumlahnya akan meningkat pada perairan yang agak keruh serta kondisi karang tidak baik, yang mana kelimpahan ikan Chaetodontidae lainnya sangat rendah (Hukom \& Bawole, (1997).

Kebiasaan makan ikan Chaetodontidae temasuk coral grazing (Bawole, 1998). Menurut Hukom \& Bawole (1997), sekitar 50\% ikan famili Chaetodontidae merupakan pemakan karang keras. Terdapat lima kategori pemangsaan ikan Chaetodontidae (kepe-kepe) yaitu (1) pemangsa karang keras (hard coral feeder), (2) invertebrata sesil termasuk polip karang (invertebrate sessile feeder), (3) invertebrata bentik, (4) omnivora dan (5) planktivor (umumnya zooplankton) (Titaheluw, 2011). Kebiasaan makan ikan Chaetodontidae bervariasi. Beberapa spesies bersifat herbivora dengan memakan alga di terumbu atau pada bagian dasar karang mati, misalnya spesies Chaetodon reticulatus. Sebaliknya ada spesies yang hanya memakan polip karang dan dikelompokan sebagai karnivora, misalnya spesies Chaetodon lunula. Adapun pemakan algae dan polip karang, sehingga spesies ini dikelompokan sebagai omnivora, misalnya Chaetodon. citrinellus, $C$. ephippium dan $C$. vagabundus (Bawole, 1998). Menurut Madduppa (2006), tidak semua ikan Chaetodontidae sebagai pemakan karang keras (scleractian coral), ada juga pemakan octocoral (karang lunak).

Ikan koralivora umumnya ditemukan berpasangan sedangkan planktivora biasanya ditemukan berkelompok (Titaheluw, 2011). Ikan Chaetodontidae pemakan karang terbagi menjadi dua kategori yaitu pemakan karang secara obligatif dan fakultatif. Pemakan karang obligatif merupakan jenis ikan Chaetodontidae yang secara khusus memakan karang, diantaranya adalah Chaetodon austriacus, C. trifascialis dan $C$. trifasciatus. Sementara pemakan karang fakultatif merupakan ikan Chaetodontidae yang mencerna berbagai macam makanan, terdiri dari polip karang, sponge, alga filamen, dan telur moluska, meliputi Chaetodon auriga, C. ephyppium, C. pelewensis, $\quad C$. lunula, $C$. ulietensis, $C$. vagabundus, Forcipiger jlavissimus dan Heniochus chrysostomus (Bawole, 1998).

Ikan famili Chaetodontiade memiliki keterkaitan sangat erat dengan terumbu karang, oleh karena itu famili ikan ini dijadikan sebagai ikan indikator kesehatan karang, karena keberadaannya dapat dipakai untuk menilai, memantau dan menduga kondisi terumbu karang. Sehingga penurunan jumlah populasi atau ketidakhadiran dari spesies ini merupakan petunjuk bahwa terumbu karang telah mengalami perubahan. (Satria \& Mujiyanto, 2011; Suryanti et al., 2011; Adrim, Syawaludin dan Kunto, 2012). Ikan Chaetodontidae adalah jenis ikan yang hidup berasosiasi paling kuat dengan karang dan sangat sensitif terhadap perubahan dan kerusakan terumbu karang karena ikan ini sangat terikat dengan sumber makanan dan tempat berlindung yang disediakan oleh karang (Titaheluw, 2011). Dari jenis ikan Chaetodontidae, obligative coral feeders merupakan jenis paling baik digunakan sebagai bioindikator kesehatan karang (Hukom \& Bawole, 1997). Menurut Nurjirana (2016), keberadaan ikan Chaetodontidae yang bersifat obligate coral feeder mengindikasikan bahwa terumbu karang masih dalam kondisi baik, khususnya untuk jenis ikan Chaetodontidae yang khusus mengkonsumsi hard coral seperti Chaetodon octofasciatus, Chaetodon trifasciatus, Chaetodon trifascialis, dan Chaetodon ornatissimus. Namun jika Chaetodon octofasciatus ditemukan dalam jumlah dominan 
mengindikasikan bahwa terumbu karang sudah mengalami perubahan, sedangkan Chaetodon trifasciatus, Chaetodon trifascialis, dan Chaetodon ornatissimus mengindikasikan bahwa kondisi karang belum mendapat gangguan atau berarti masih relatif baik (Madduppa, 2006).

Kepulauan Togean merupakan salah satu Taman Nasional di Indonesia yang terletak di Teluk Tomini dan memiliki kekayaan hayati bawah laut sangat besar. Taman Nasional Kepulauan Togean (TNKT) berada dalam wilayah administratif Kabupaten Tojo Una-Una, Sulawesi Tengah dan mempunyai 6 pulau utama yang memanjang dari barat ke timur, yaitu Pulau Unauna, Pulau Batudaka, Pulau Togean, Pulau
Talatakoh, Pulau Waleakodi, dan Pulau Waleabahi (Sulistiawati, Lucky, Ismudi dan Abdul., 2012). Tujuan dari penelitian ini adalah mengamati komposisi jenis dan sebaran serta mengkaji bioekologi ikan famili Chaetodontidae di perairan Taman Nasional Kepulauan Togean, Provinsi Sulawesi Tengah.

\section{BAHAN DAN METODE}

Penelitian ini telah dilaksanakan pada Februari sampai Mei 2017, di Taman Nasional Kepulauan Togean, Provinsi Sulawesi Tengah (Gambar 1).

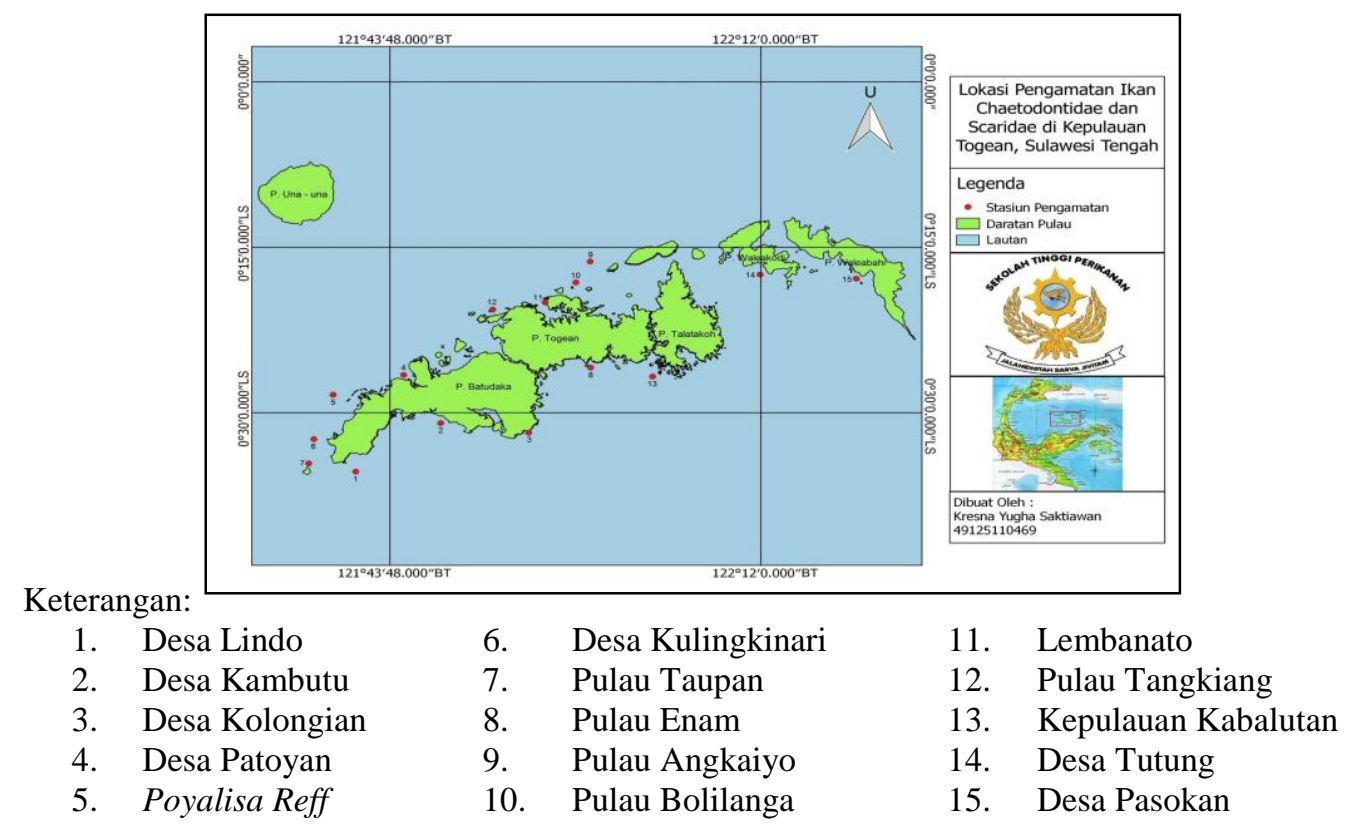

Gambar 1. Lokasi penelitian di Taman Nasional Kepulauan Togean, Provinsi Sulawesi Tengah Figure 1. Research location in Togean Islands National Park, Central Sulawesi Province

Metode penelitian yang digunakan adalah metode survey, data yang dikumpulkan adalah jenis ikan, jumlah ikan, analisis makanan dan kebiasaan makan ikan serta parameter lingkungan perairan. Pengambilan data ikan Chaetodontidae menggunakan metode Line Intercept Transect (LIT). Identifikasi ikan dilakukan dengan Underwater Visual Census (UVC) dengan bantuan kamera untuk mendokumentasi spesies ikan yang belum teridentifikasi ketika penyelaman (Nurjirana, 2016). Jenis ikan diidentifikasi melalui hasil video yang telah direkam pada saat penyelaman dengan menggunakan buku identifikasi Allen, Steene, Human and Deloach Copyright (C) Jkpt Juni 2018 Kajian Bioekologi Ikan Karang Chaetodontidae
(2003), Allen and Mark (2012), Kuiter and Tonozuka (2001) dan Setiawan (2010). Kelimpahan jenis ikan dihitung sepanjang garis transek 70 meter 2,5 meter ke kiri dan kanan garis transek. Jenis makanan dan kebiasaan makan ikan dilakukan dengan mengidentifikasi isi perut ikan. Parameter perairan yang diamati adalah suhu, kecerahan, kecepatan arus dan salinitas.

Analisis untuk kelimpahan ikan menggunakan persamaan sebagai berikut (English,Wilkinson and Baker, 1997) :

Keterangan : $\quad \mathbf{N}=\frac{\mathrm{ni}}{\mathrm{A}}$ 
D $=$ Kelimpahan Spesies (Ind/ha)

$\mathrm{n}_{\mathrm{i}} \quad$ = Jumlah Individu ikan jenis ke-i

$\mathrm{A} \quad=$ Luas area sensus ikan

Analisis untuk mengetahui keanekaragaman jenis ikan menggunakan rumus Shannon-Wiener (Tuhumena, 2013). Analisis kebiasaan makan ikan dihitung menggunakan metode indeks bagian terbesar (Indeks of Preponderance) (Titrawani, Elvyra dan Sawalia, 2013), sebagai berikus:

$$
\text { IP }(\%)=\frac{V i \times O i \times 100}{\sum(\mathrm{Vi} \times \mathrm{Oi})}
$$

dimana: $\mathbf{V i}=\frac{\sum \text { individu satu jenis }}{\sum \text { seluruh jenis }} \times \mathbf{1 0 0 \%}$

$$
\mathbf{O i}=\frac{\sum \text { lambung yang berisi satu jenis makanan }}{\sum \text { seluruh lambung yang berisi makanan }} \times \mathbf{1 0 0 \%}
$$

Keterangan :

IP = Indeks of Preponderance

$\mathrm{Vi}=$ Persentase volume satu jenis makanan

Oi $=$ Persentase frekuensi kejadian satu macam makanan

Katagori urutan makanan dibedakan dalam tiga kategori berdasarkan persentase Index of Preponderance (IP) (Sentosa dan Hendra, 2011) yaitu:

$$
\begin{array}{ll}
\text { IP }>25 \% & =\text { Makanan utama } \\
5 \% \leq \mathrm{IP} \leq 25 \% & =\text { Makanan pelengkap } \\
\text { IP }<5 \% & =\text { Makanan tambahan }
\end{array}
$$

Status ekologi ikan ikan Chaetodontidae digunakan nilai indeks ekologi dengan melihat kriteria skoring (McMellor, 2007). Untuk mengetahui tingkat kesamaan keberadaan jenis-jenia ikan yang dikelompokkan menggunakan analisia klaster, pengelompokan lokasi pengamatan terhadap kehadiran spesies ikan Chaetodontidae dan mengelompokan kesamaan ikan Chaetodontidae yang ditemukan disekitar lokasi pengamatan. Pengolahan data analisa pengelompokan dilakukan dengan bantuan program STATISTICA.

\section{HASIL DAN PEMBAHASAN}

Berdasarkan hasil pengamatan yang telah dilakukan di wilayah perairan Taman Nasional Kepulauan Togean, ikan family Chaetodontidae ditemukan dilima pulau besar (15 stasiun), yaitu terdiri 3 genera dan 12 spesies, kehadiran dan kelimpahan ikan Chaetodontidae disajikan dalam Tabel 1. Kehadiran dan jumlah spesies ikan Chaetodontidae tertinggi berada di Pulau Togean sebesar 343 ind/ha dan terendah berada di Pulau Waleakodi sebesar 86 ind/ha. Tingginya kehadiran dan jumlah ikan Chaetodontidae di Pulau Togean diduga karena kondisi terumbu karang yang masih dalam keadaan baik dan beranekaragamnya jenis terumbu karang yang ditemukan. Seperti pendapat Titaheluw (2011), dalam siklus hidup ikan Chaetodontidae memiliki ketergantungan terhadap terumbu karang yang berperan sebagai sumber makanan dan tempat berlindung oleh karena itu

\begin{tabular}{|c|c|c|c|c|c|c|c|}
\hline \multirow[b]{2}{*}{ No } & \multirow[b]{2}{*}{ Spesies } & \multicolumn{6}{|c|}{ Kelimpahan ikan (ind/ha) } \\
\hline & & $\begin{array}{c}\text { Pulau } \\
\text { Batudaka }\end{array}$ & $\begin{array}{c}\text { Pulau } \\
\text { Togean }\end{array}$ & $\begin{array}{c}\text { Pulau } \\
\text { Talatakoh }\end{array}$ & $\begin{array}{c}\text { Pulau } \\
\text { Waleakodi }\end{array}$ & $\begin{array}{c}\text { Pulau } \\
\text { Waleabahi }\end{array}$ & Jumlah \\
\hline 1. & Chaetodon baronessa & 8 & 0 & 29 & 29 & 0 & 65 \\
\hline 2. & C. kleinii & 24 & 40 & 0 & 29 & 0 & 93 \\
\hline 3 & C. lunulatus & 12 & 17 & 0 & 0 & 29 & 58 \\
\hline 4. & C. melannotus & 4 & 34 & 0 & 29 & 0 & 67 \\
\hline 5. & C. ornatissimus & 0 & 11 & 0 & 0 & 0 & 11 \\
\hline 6. & C. punctatofasciatus & 16 & 91 & 114 & 0 & 0 & 222 \\
\hline 7. & C. rafflesi & 0 & 11 & 0 & 0 & 0 & 11 \\
\hline 8. & C. semelon & 0 & 11 & 0 & 0 & 0 & 11 \\
\hline 9. & C. ulietensis & 8 & 6 & 0 & 0 & 0 & 14 \\
\hline 10. & C. vagabundus & 4 & 11 & 0 & 0 & 29 & 44 \\
\hline 11. & Forcipiger jlavissimus & 16 & 80 & 0 & 0 & 29 & 125 \\
\hline 12. & Heniochus varius & 20 & 29 & 171 & 0 & 57 & 278 \\
\hline & Jumlah & 114 & 343 & 314 & 86 & 143 & 1.000 \\
\hline
\end{tabular}
distribusi dan densitasnya lebih banyak dipengaruhi oleh kondisi tutupan karang hid

Tabel 1. Kehadiran dan Kelimpahan Ikan Chaetodontidae di Perairan Taman Nasional Kepulauan Togean.

Table 1. Presence and abundance of Chaetodontidae fish in the waters of the Togean Islands National Park 
Suryanti et al. (2011), yang menyatakan bahwa ikan Chaetodontidae merupakan ikan yang akan dijumpai pada setiap komunitas terumbu karang dalam keadaan baik. Sementara Sadarun (2011), menyatakan bahwa keanekaragaman dan tutupan karang hidup sangat berkaitan dengan kelimpahan ikan Chaetodontidae, sehingga jumlah dan jenis ikan ini sebanding dengan jenis karang yang ditemukan. Hal tersebut diperkuat dengan ditemukannya spesies Chaetodon ornatissimus di Pulau Togean. Menurut Madduppa (2006), kehadiran Chaetodon ornatissimus mengindikasikan bahwa kondisi terumbu karang belum mendapatkan gangguan yang berarti atau masih relatif baik. Rendahnya nilai kelimpahan ikan Chaetodontidae di Pulau Waleakodi diduga karena keadaan terumbu karangnya telah mengalami kerusakan yang dapat mempengaruhi kelimpahan, distribusi dan densitas ikan Chaetodontidae. Spesies Heniochus varius ditemukan hampir disemua lokasi pengamatan. Hal tersebut diduga karena lebih banyak lokasi pengamatan yang berada disekitar tubir. Pendapat Bawole (1998), Heniochus sp. merupakan jenis ikan yang menyenangi daerah tubir terumbu. Sementara rendahnya jumlah dan kehadiran spesies ikan Chaetodontidae di Pulau Waleakodi diduga karena kondisi terumbu karangnya telah mengalami kerusakan. Utomo (2010), yang menyatakan bahwa baik dan buruknya kondisi terumbu karang akan menentukan kehadiran dan distribusi ikan Chaetodontidae.

Hasil analisis indeks biologi ikan Chaetodontidae dapat dilihat pada Gambar 1. Nilai indeks keanekaragaman (H') ikan Chaetodontidae termasuk dalam kategori keanekaragaman rendah sampai sedang dengan kisaran antara 0,92-2,05. Lokasi pengamatan yang termasuk dalam kategori rendah adalah Pulau

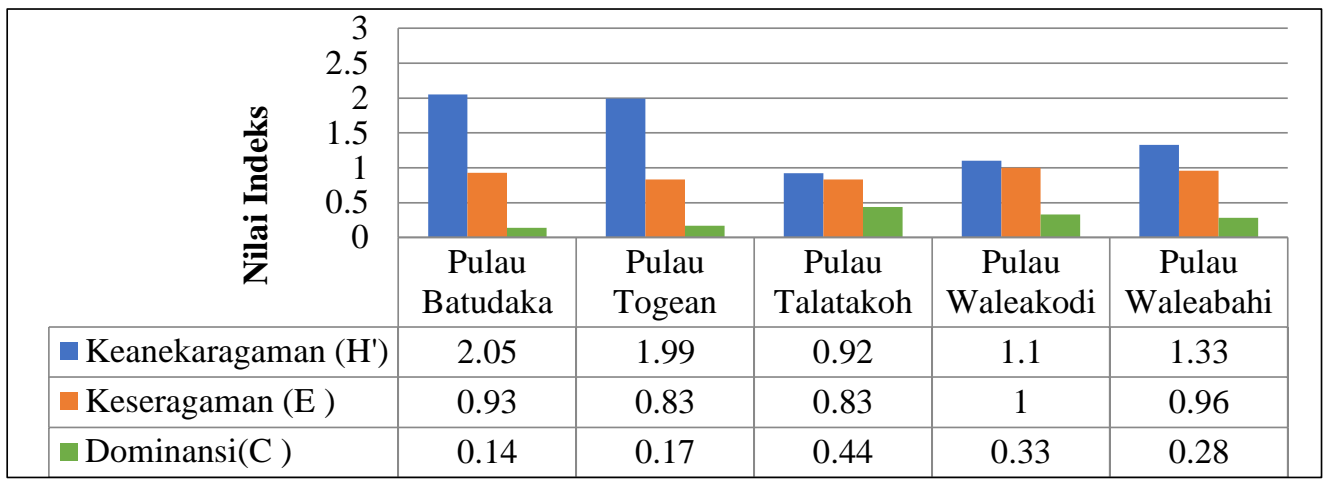

Gambar 2. Nilai Indeks Biologi Ikan Famili Chaetodontidae di Perairan Taman Nasional Kepulauan Togean Figure 2. Biet index value of Chaetodontidae family in the waters of the Togean Islands National Park

Talatakoh. Rendahnya nilai keanekaragaman di Pulau Talatakoh diduga karena sedikitnya spesies yang ditemukan di lokasi tersebut. Sementara lokasi pengamatan yang termasuk dalam kategori sedang adalah Pulau Waleakodi, Pulau Waleabahi, Pulau Togean sedangkan Pulau Batudaka yang memiliki nilai keanekaragaman tertinggi. Tingginya nilai keanekaragaman di Pulau Batudaka diduga karena banyaknya spesies ikan Nasional Kepulauan Togean dalam keadaan stabil. Seperti pendapat Ratnawati, Hamelia dan Sukmaharja (2011), yang menyatakan bahwa jika nilai keseragaman lebih dari 0,6 menandakan bahwa komunitas biota dalam keadaan stabil. Nilai indeks dominansi (C) termasuk dalam kategori rendah dengan kisaran antara $0,14-0,44$.
Chaetodontidae yang ditemukan dengan jumlah individu yang hampir sama tiap spesiesnya. Nilai indeks keseragaman (E) menunjukan dalam kategori keseragaman tinggi dengan kisaran antara 0,83 - 1,00. Tingginya nilai keseragaman ikan Chaetodontidae ditiap lokasi pengamatan tersebut diduga karena tidak adanya spesies yang mendominasi sehingga menunjukan keadaan komunitas ikan Chaetodontidae yang ada di wilayah Taman

Rendahnya nilai dominansi tersebut diduga karena ikan Chaetodontidae menyebar secara merata dan memiliki jumlah individu yang hampir sama (tidak ada spesies yang mendominasi) disetiap lokasi pengamatan. Hal itu menjadi dugaan bahwa komunitas ikan Chaetodontidae yang ada di perairan Taman Nasional Kepulauan Togean 
berada dalam keadaan stabil dan tidak terjadi tekanan ekologis di wilayah tersebut.

Hasil analisis jenis dan jumlah makanan yang dikonsumsi ikan Chaetodontidae disajikan pada Gambar 2, ditemukan adanya 8 jenis makanan. Jenis makanan yang mendominasi adalah zat kapur (62,36\%) diikuti oleh zooxanthellae $(33,71 \%)$, sehingga terdapat dugaan bahwa zat kapur dan zooxanthellae sebagai makanan

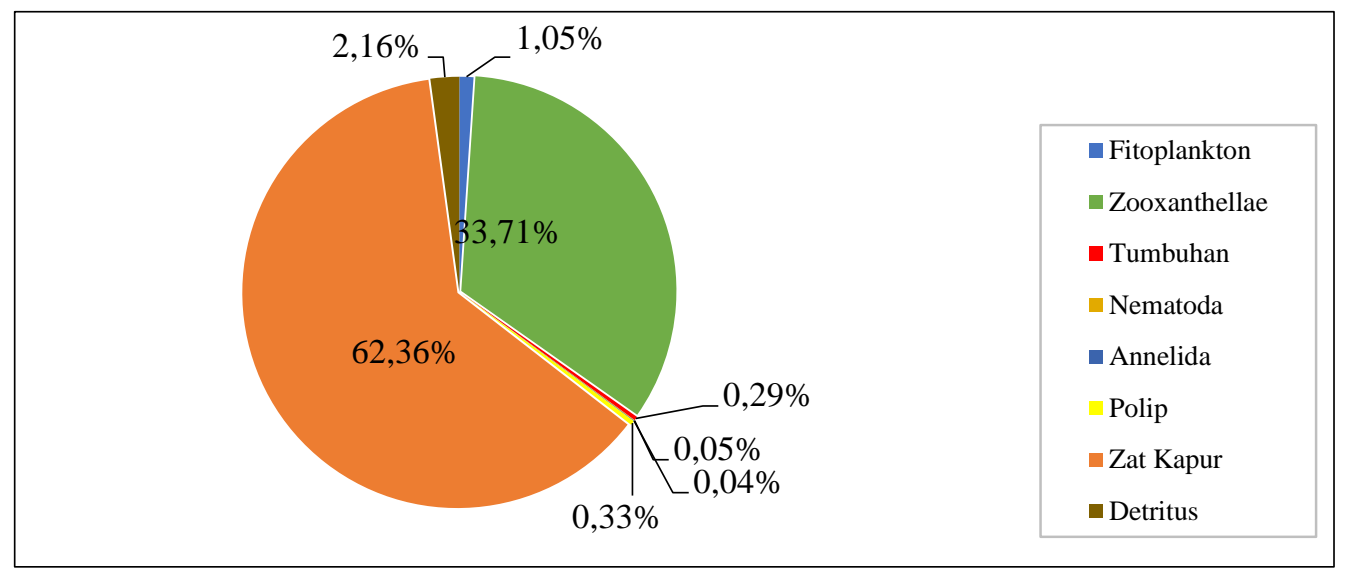

Gambar 3. Kandungan Isi Perut Ikan Chaetodontidae

Figure 3. Contents of Chaetodontidae Fish Stomach

utama ikan tersebut. Sentosa \& Hendra (2011), yang menyatakan bahwa jika IP > 25\% maka kandungan tersebut menjadi makanan utama. Selain itu banyaknya kandungan zat kapur dan zooxanthellae menunjukan bahwa dalam kehidupannya ikan Chaetodontidae memiliki hubungan yang erat dengan ekosistem terumbu karang. Hal itu sesuai dengan pendapat Hukom \& Bawole (1997), yang menyatakan bahwa ikan Chaetodontidae hidup berasosiasi dengan terumbu karang dan dianggap sebagai penghuni terumbu karang sejati.

Selain kedua jenis makan tersebut, ditemukan juga jenis detritus $(2,16 \%)$, fitoplankton $(1,05 \%)$, polip $(0,33 \%)$, tumbuhan $(0,29 \%)$, nematoda $(0,05 \%)$ dan annelida $(0,04 \%)$. Dari hasil tersebut maka dapat diketahui bahwa ikan Chaetodontiade tidak hanya bersifat hard coral feeder namun juga bersifat invertebrate sessile feeder, invertebrata bentik, omnivora dan planktivor. Titaheluw (2011), yang menyatakan bahwa ikan Chaetodontidae memiliki 5 kategori pemangsaan. Selain itu, sedikitnya jenis makanan tersebut menjadi dugaan bahwa jenis tersebut termasuk kategori makanan tambahan ikan Chaetodotidae. Namun juga, terdapat dugaan bahwa sedikitnya persentase jenis makanan tersebut karena terbawa saat terjadi pemangsaan ikan Chaetodontidae.

Copyright (C) Jkpt Juni 2018

Kajian Bioekologi Ikan Karang Chaetodontidae
Hasil penilaian ekologi ikan Chaetodontidae berdasarkan nilai skoring kelimpahan ikan ditiap lokasi pengamatan menurut Mc.Mellor (2007) disajikan pada Tabel 2. Berdasarkan hasil penilaian ekologi ikan Chaetodontidae diketahui bahwa yang tergolong dalam kriteria sangat baik adalah Pulau Togean, Pulau Talatakoh dan Pulau Waleabahi serta kriteria baik terdapat di Pulau Batudaka. Sementara Pulau Waleabahi termasuk dalam kriteria buruk berdasarkan penilaian ekologi kondisi ikan Chaetodontidae. Baik dan buruknya kondisi ikan Chaetodontidae di lokasi pengamatan diduga ada kaitannya dengan habitat ikan itu sendiri yaitu ekosistem terumbu karangnya, karena ikan Chaetodontidae memiliki ketergantungan sangat kuat terhadap terumbu karang sebagai sumber makanan dan tempat berlindung. Seperti pendapat Sumadhiharga (2006) dan Utomo (2010), yang menyatakan bahwa baik dan buruknya kondisi terumbu karang akan menentukan kehadiran, distribusi dan kelimpahan ikan Chaetodontidae yang menghuni perairan tersebut. Oleh karena itu, terdapat dugaan bahwa semakin tinggi nilai skoring ikan Chaetodontidae maka semakin baik juga keadaan terumbu karangnya. 
Tabel 2. Kondisi Ikan Chaetodontidae berdasarkan Kriteria Penilaian Ekologi Ikan Karang di Perairan

Taman Nasional Kepulauan Togean (Mc.Mellor, 2007).

Table 2. Chaetodontidae Fish Condition based on the Criteria for Ecological Assessment of Coral Fish in the Togean Islands National Park Waters (Mc.Mellor, 2007).

\begin{tabular}{|c|l|c|c|c|c|}
\hline No & \multicolumn{1}{|c|}{ Lokasi Pengamatan } & $\begin{array}{c}\text { Individu yang } \\
\text { ditemukan }\end{array}$ & Jumlah & Skor & Kriteria \\
\hline 1. & Pulau Batudaka & 7 & $>6$ & 3 & Baik \\
\hline 2. & Pulau Togean & 21 & $>8$ & 5 & Sangat baik \\
\hline 3. & Pulau Talatakoh & 19 & $>8$ & 5 & Sangat baik \\
\hline 4. & Pulau Waleakodi & 5 & $>4$ & 1 & Buruk \\
\hline 5. & Pulau Waleabahi & 9 & $>8$ & 5 & Sangat baik \\
\hline
\end{tabular}

Hasil analisis kelompok untuk melihat distribusi antar lokasi penelitian dengan menggunakan tingkat kesamaan kehadiran dari masing-msing spesies ikan famili Chaetodontidae terdapat dua kelompok besar yang memiliki kehadiran spesies yang sama (Gambar 3). Kelompok pertama adalah Pulau Waleabahi, Pulau Waleabahi, Pulau Talatakoh dan Pulau Batudaka. Sedangkan kelompok kedua adalah Pulau Togean yang diduga memiliki perbedaan signifikan dengan pulau lainnya. Diantara kedua kelompok besar tersebut terdapat satu kelompok kecil yang diduga memiliki kemiripan sangat dekat, yaitu Pulau Waleabahi dan Pulau Waleakodi dengan nilai skala pesentase $18,79 \%$. Mujiyanto \& Hartati (2011), yang menyatakan bahwa semakin kecil nilai skala persentase maka memiliki tingkat kemiripan semakin tinggi. Hal tersebut dibuktikan dengan hampir samanya kehadiran spesies ikan Chaetodontidae yang ditemukan dilokasi tersebut dibandingkan dengan lokasi pengamatan yang lainnya

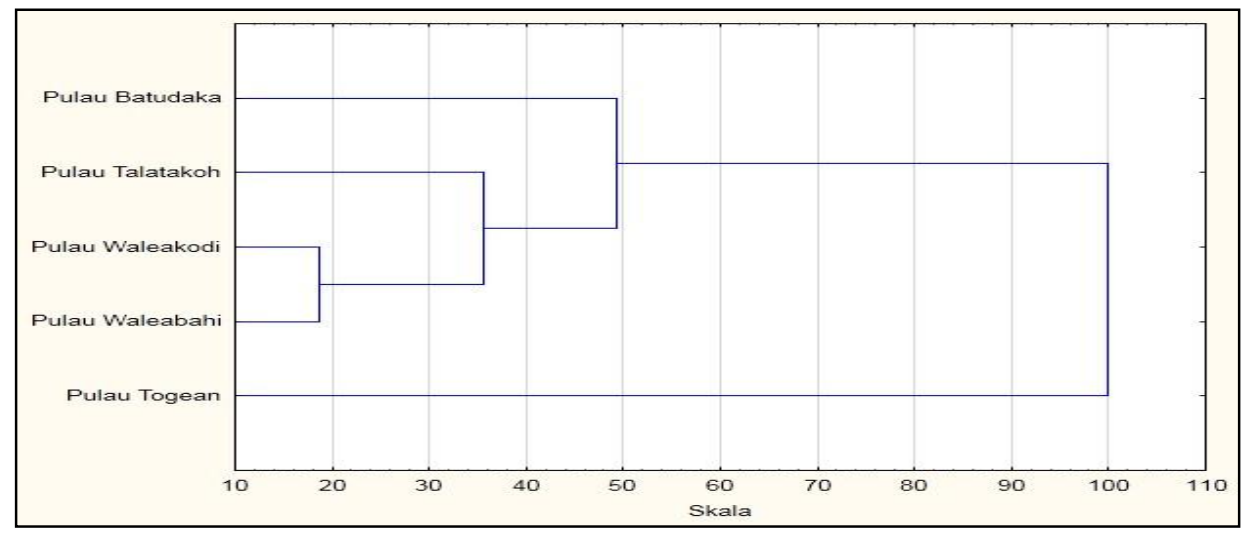

Gambar 4. Tingkat Kesamaan Lokasi Pengamatan berdasarkan Kehadiran Spesies Ikan Chaetodontidae yang Ditemukan di Perairan Taman Nasional Kepulauan Togean Figure 4. Level of Similarity of Observation Location based on Presence of Chaetodontidae Fish Species Found in the Waters of Togean Islands National Park

Hasil analisis pengelompokan kemiripan jumlah dan kehadiran ikan Chaetodontidae yang ditemukan pada lokasi pengamatan disajikan pada Gambar 4. Hasil analisis klaster pada dendogram tingkat kesamaan jenis ikan Chaetodontidae menunjukan bahwa terdapat dua kelompok besar. Copyright (C) Jkpt Juni 2018 Kajian Bioekologi Ikan Karang Chaetodontidae
Kelompok pertama yaitu Chaetodon rafflesi, $C$. semelon, $C$. ornatissimus, $C$. ulietensis, $C$. vagabundus, $C$. baronessa, $C$. lunulatus, $C$. melannotus, $\quad C$. kleinii dan Chaetodon punctatofasciatus. Sedangkan kelompok kedua yaitu Heniochus varius dan forcipiger jlavissimus. 
Diantara kedua kelompok besar tersebut terdapat satu kelompok kecil yang diduga memiliki kemiripan sangat dekat, yaitu Chaeoton rafflesi dan Chaetodon semelon dengan nilai skala persentase 6,92\%. Selain itu, ditemukan juga kemiripan antara Heniochus varius dan Forcipiger jlavissimus dengan nilai skala persentase $61,66 \%$.
Kemiripan tersebut sesuai dengan pendapat Bawole (1998), yang menyatakan bahwa Heniochus spp. dan Forcipiger spp. merupakan jenis ikan yang menyenangi daerah tubir terumbu atau drop off. Sehingga terdapat dugaan bahwa kedua spesies tersebut memiliki hubungan kehadiran yang erat.

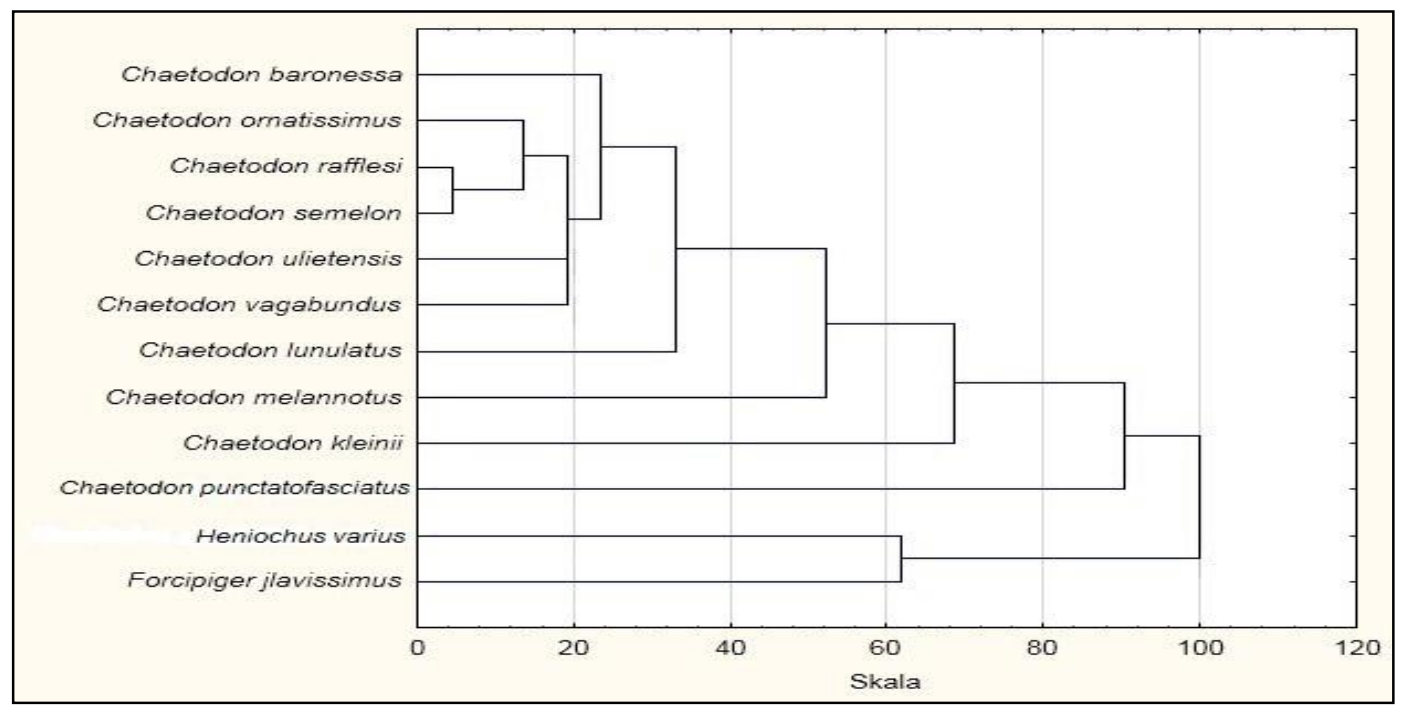

Gambar 5. Tingkat Kesamaan Jenis-jenis Ikan Chaetodontidae antar Lokasi Pengamatan di Perairan Taman Nasional Kepulauan Togean

Figure 5. Level of Similarity of the Types of Chaetodontidae Fish between Observation Locations in the Waters of the Togean Islands National Park

Hasil pengamatan terhadap parameter kondisi perairan menunjukan bahwa kondisi kualitas perairan tidak jauh berbeda pada setiap lokasi pengamatan (Tabel 3).

Tabel 3. Nilai Kualitas Perairan disetiap Lokasi Pengamatan

Table 3. Value of Water Quality in each Observation Location

\begin{tabular}{|l|c|c|c|c|}
\hline \multirow{2}{*}{\multicolumn{1}{c|}{ Lokasi Pengamatan }} & \multicolumn{4}{|c|}{ Parameter Kualitas Air } \\
\cline { 2 - 5 } & Kecerahan $(\mathbf{m})$ & Kec. Arus $(\mathbf{m} / \mathbf{s})$ & Salinitas (\%o) & Suhu $\left({ }^{\circ} \mathbf{C}\right)$ \\
\hline Pulau Batudaka & $5,40-5,70$ & $0,15-0,33$ & $27-32$ & $30-32$ \\
\hline Pulau Togean & $5,30-6,40$ & $0,07-0,22$ & $29-32$ & $30-31$ \\
\hline Pulau Talatakoh & 5,10 & 0,50 & 28 & 31 \\
\hline Pulau Waleakodi & 5,90 & 0,14 & 28 & 32 \\
\hline Pulau Waleabahi & 5,35 & 0,12 & 24 & 32 \\
\hline $\begin{array}{l}\text { Standar Baku mutu } \\
\text { (Kepmen LH, 2004) }\end{array}$ & $>5$ & - & $33-34$ & $28-30$ \\
\hline
\end{tabular}

Tingkat kecerahan dengan kisaran 5,10 $6,75 \mathrm{~m}$. Nilai kecerahan tersebut termasuk tinggi dan sesuai dengan standar baku mutu untuk kehidupan biota laut menurut Kepmen LH tahun 2004. Nilai kecepatan arus memiliki perbedaan disetiap lokasi pengamatan dengan kisaran 0,07 -
$0,50 \mathrm{~m} / \mathrm{s}$. Kecepatan arus tertinggi berada di Pulau Talatakoh dengan nilai $0,50 \mathrm{~m} / \mathrm{s}$ dan terendah berada di Pulau Togean dengan nilai $0,07 \mathrm{~m} / \mathrm{s}$. Seperti pendapat Arfiatin, Agung dan Max. (2013), yang menyatakan bahwa perbedaan nilai kecepatan arus dapat dipengaruhi oleh angin, gelombang dan

Copyright (C) Jkpt Juni 2018

Kajian Bioekologi Ikan Karang Chaetodontidae ........Suharti, et.al 
musim. Nilai salinitas berkisar antara 24- $32 \%$, salinitas tersebut tergolong rendah dan dibawah standar baku mutu untuk kehidupan biota karang menurut Kepmen LH tahun 2004. Nilai salinitas disekitar perairan Kepulauan Togean masih cenderung baik untuk pertumbuhan dan perkembangan biota karang. Rendahnya nilai salinitas di Pulau Waleabahi dikarenakan lokasi pengamatan yang berdekatan dengan muara sungai. Pendapat tersebut diperkuat oleh Islami (2013), yang menyatakan bahwa salinitas dipengaruhi masukan air sungai, genangan pasang surut serta intensitas penguapan yang terjadi di laut. Suhu berkisar antara $30-32^{\circ} \mathrm{C}$, kisaran suhu tersebut masih tergolong wajar untuk kehidupan biota karang di perairan tropis, dimana suhu di perairan tropis berkisar antara $25,6-32,3^{\circ} \mathrm{C}$.

\section{KESIMPULAN}

Diversitas ikan family Chaetodontidae terdiri dari 3 genera dan 12 spesies dengan kehadiran dan jumlah spesies tertinggi di Pulau Togean, kelimpahan tertinggi dimiliki oleh Heniochus varius (278 ind/ha). Indeks keanekaragaman $\left(\mathrm{H}^{\prime}\right)$ ikan Chaetodontidae tergolong kategori rendah sampai sedang, indeks keseragaman (E) tergolong kategori tinggi serta indeks dominansi (C) tergolong rendah. Hasil analisis makanan dan kebiasaan makan menunjukan bahwa ikan Chaetodontidae bersifat hard coral feeder. Hasil penilaian ekologi terhadap ikan Chaetodontidae menunjukan bahwa keadaan terumbu karang di perairan Taman Nasional Kepulauan Togean masih dalam keadaan baik, kecuali pada Pulau Waleakodi cenderung telah mengalami kerusakan pada ekosistem terumbu karangnya. Pengelompokan kesamaan spesies membentuk kelompok yang mengerucut ke perairan Pulau Togean, menunjukkan bahwa hampir seluruh spesies ikan family Chaetodontidae ditemukan terdapat di Pulau Togean. Hasil analisis klaster menunjukan bahwa Pulau Waleakodi dan Pulau Waleabahi memiliki kesamaan keadaan terumbu karang terdekat diantara pulau lainnya. Spesies yang memiliki kesamaan kehadiran adalah Heniochus varius dan Forcipiger jlavissimus. Keadaan perairan di wilayah Taman Nasional Kepulauan Togean tergolong masih layak untuk mendukung pertumbuhan dan perkembangan ikan karang meskipun hanya kecerahan yang sesuai dengan standar baku mutu KepMen LH tahun 2004.

\section{DAFTAR PUSTAKA}

Adrim, M., Syawaludin A. H. \& Kunto W. (2012). Struktur Komunitas Ikan Karang di Perairan Kendari. Jurnal Ilmu Kelautan. Vol 17 (3), 154-163.

Allen, G., Steene R., Humann P. \& Deloach N. (2003). Reef Fish Indentification Tropical Pasific. New World Publications, Jacksonville, 480 pp.

Allen, G. R. \& Mark V. E. (2012). Reef Fishes of The East Indies. Volume II. Tropical Reef Research, Perth, Australia.

Arfiatin, S.W., Agung S. \& Max R.M. (2013). Analisis Sebaran Klorofil-a dan Kualitas Air di Ekosistem Sekitar PT Kayu Lapis Indonesia (Pantai, Muara, Tambak) Kaliwungu, Kendal. Diponegoro Journal of Maquares. Vol 2 (4), 110-117.

Bawole, R. (1988). Distribusi Spasial Ikan Chaetodontidae dan Peranannya sebagai Indikator Kondisi Terumbu Karang di Perairan Teluk Ambon. Tesis. Program Studi Ilmu Kelautan: Institut Pertanian Bogor. Bogor. Link

English S., C.Wilkinson, \& V. Baker, 1997. Survey Manual For Tropical Marine Resource $\left(2^{\text {nd }}\right.$ Edition). Australian Institute of Marine Science. Australia. X; 330p.

Hukom, F.D \& R. Bawole. (1997). Famili Chaetodontidae sebagai Ikan Indikator di Daerah Terumbu Karang. Jurnal Lonawarta. Vol XX (1), 1-6.

Islami, M.M. (2013). Pengaruh Suhu dan Salinitas terhadap Bivalvia. Jurnal Oceana. Vol 28 (2), 1-10.

Kementerian Lingkungan Hidup., (2004). Keputusan Menteri Lingkungan Hidup Nomor 51 tahun 2004 tentang Baku Mutu Air Laut.

Kuiter, R. H. \& Tonozuka T., (2001). Pictorial Guide to Indonesian Reef Fishes Zoonetics.

Madduppa, H.H. (2006). Kajian Ekobiologi ikan Kepe-Kepe (Chaetodon Octofasciatus, 
Bloch 1787) Dalam Mendeteksi Kondisi Ekosistem Terumbu Karang Di Pulau Petondan Timur, Kepulauan Seribu, Jakarta. Tesis. Program Studi Ilmu Kelautan: Institut Pertanian Bogor. Bogor. Link

Maharbhakti, H. R. (2009). Hubungan Kondisi Terumbu Karang dengan Keberadaan Ikan Chaetodontidae di Perairan Pulau Abang, Batam. Tesis. Program Studi Ilmu Pengelolaan Sumberdaya Pesisir dan Lautan: Institut Pertanian Bogor. Bogor. Link

Mc. Mellor, S. (2007). A Conservation Value Index to Facilitate Coral Reef Evaluation and Assesmant. Thesis Submitted for the Degree of Doctor of Philosophy. Department of Biological Sciences: University of Essex, UK.

Mujiyanto \& Hartati. S. T. (2011). Komposisi dan Kelimpahan Stok Ikan Karang serta Pertumbuhan Biota Penempel pada Terumbu Karang Buatan di Teluk Saleh, Nusa Tenggara Barat. Jurnal Penelitian Perikanan Indonesia. Vol 17 (1), 51-59.

Nurjirana. (2016). Kelimpahan dan Keragaman Jenis Ikan Famili Chaetodontidae berdasarkan Kondisi Tutupan Karang Hidup di Kepulauan Spermonde Sulawesi Selatan. Skripsi. Program Studi Ilmu Kelautan: Universitas Hasanuddin. Makasar.

Ratnawati, P., Hamelia P. \& Sukmaharja. (2011). Kondisi dan Potensi Komunitas Ikan Karang di Wilayah Kepulauan Kayoa, Kabupaten Halmahera Selatan Maluku Utara. Prosiding Seminar Nasional Pengembangan Pulau-Pulau Kecil. Link

Sadarun, B. (2011). Proses Tertangkapnya Ikan Karang dengan Small Bottom Setnet. Tesis. Program Studi Teknologi Kelautan: Institut Pertanian Bogor. Bogor. Link

Satria, H., \& Mujiyanto. (2011). Struktur Komunitas Ikan Karang di Lokasi Terumbu Karang Buatan di Perairan Teluk Saleh, Nusa Tenggara Barat. Prosiding Forum Nasional Pemacuan Sumber Daya Ikan III: Konservasi bagi kelestarian sumberdaya dan kestabilan produksi ikan. Kerjasama BP2KSI, FPIK UNPAD, LIPI dan MII. 18 Oktober 2011. Hal. KSI-10 (116) $\underline{\text { Link }}$

Sentosa, A.A.\& Hendra S. (2011). Relung Ekologi Beberapa Ikan Target Hasil Tangkapan Bubu di Sekitar Terumbu Buatan Perairan Teluk Saleh, Nusa Tenggara Barat. Jurnal Penelitian Perikanan Indonesia. Vol 17 (3), 209-219.

Setiawan, F. (2010). Identifikasi Ikan Karang dan Invertebrata Laut. Manado, Indonesia. Link

Sulistiawati, D., Lucky A., Ismudi M. \& Abdul M. (2012). Penilaian Dampak Biodiversitas Laut (Kasus Gugus Pulau Batudaka Provinsi Sulawesi Tengah). Jurnal Bumi Lestari. Vol 12 (2), 226-238.

Sumadhiharga, O. K. (2006). Keanekaragaman Jenis Ikan Karang di Perairan Belitung Barat, Kepulauan Bangka Belitung. Jurmal Ilmu Kelautan. Vol 11 (4), 201-29.

Suryanti, Supriharyono \& Wily I. (2011). Kondisi Terumbu Karang dengan Indikator Ikan Chaetodontidae di Pulau Sambangan Kepulauan Karimun Jawa, Jepara, Jawa Tengah. Buletin Oseanografi Marina. Vol 1 (1), 106-119.

Titaheluw, S. (2011). Keterkaitan antara Terumbu Karang dengan Ikan Chaetodontidae: Implikasi untuk Pengelolaan. Tesis. Fakultas Ilmu Kelautan: Institut Pertanian Bogor. Bogor.

Titrawani, T., Elvyra, R., \& Sawalia, R. U. (2013). Analisis Isi Lambung Ikan Senangin (Eleutheronema tetradactylum Shaw) di Perairan Dumai. Al-Kauniyah: Jurnal Biologi. Vol 6 (2), 85-90.

Utomo, S. P. (2010). Kajian Hubungan Kondisi Terumbu Karang dengan Kelimpahan Ikan Chaetodontidae di Kawasan Konservasi Laut daerah Pulau Liwutongkidi, Kabupaten Buton. Tesis. Program Studi Ilmu Pengelolaan Sumberdaya Pesisir dan Lautan: Institut Pertanian Bogor. Bogor. $\underline{\text { Link }}$

Copyright (c) Jkpt Juni 2018

Kajian Bioekologi Ikan Karang Chaetodontidae ........Suharti, et.al 